\title{
Immobilisation of marine pectinase on nylon 6,6
}

\begin{abstract}
Industries all over the world face an uphill battle in meeting the material needs of a rising global population at a time when natural resources are dwindling. By replacing harsh chemicals with biologically derived alternatives and at the same time minimizing water and energy use, sustainability is at heart of the world's growth. Perhaps nowhere has the impact of modern biotechnology been more widely felt than in the application of industrial enzymes? Enzymes represent lucrative option to substitute harsh chemicals used in processing operations in different industries. Enzymes being target specific and biodegradable are looked upon as lucrative source for providing clean and green substitute to harsh chemicals used in different industries. Pectinase is one of the enzymes that acts as alternative to chemicals used in different textile processing operations. The current demands of the world's biotechnological industries are enhancement in enzyme productivity and development of novel techniques for increasing their shelf life. These requirements are inevitable to facilitate large-scale and economically feasible formulation. Immobilizing pectinase by suitable technique allows its reusability and in turn will make pectinase economical. In this research, immobilization of pectinase on knitted nylon 6,6 fabric is studied which showed immobilized biocatalyst could be used successively; effectively upto three cycles.
\end{abstract}

Keywords: marine pectinase, bacillus subtilis, enzyme, immobilization, nylon 6,6

\author{
Volume 4 Issue 2 - 2018
}

\author{
Manasi Damle, Pallavi Badhe, Geetal Mahajan, \\ Adivarekar RV \\ Department of Fibres and Textile Processing Technology, \\ Institute of Chemical Technology, India
}

Correspondence: Adivarekar RV, Department of Fibres and Textile Processing Technology, Institute of Chemical Technology, Mumbai, India, Tel (+91) 982I227276,

Email rv.adivarekar@ictmumbai.edu.in

Received: November 22, 2017 | Published: April 09, 2018

\section{Introduction}

Enzymes are biocatalysts, which enhance the rate of chemical reactions. They are naturally occurring substances, capable of catalysing specific chemical reactions and hence called 'biocatalysts'. Enzymes act on substrate molecule by hydrolysis, beta elimination mechanism etc. Like all catalysts, enzymes work by lowering the activation energy for a reaction and thus dramatically accelerating the rate of the reaction. As with all catalysts, enzymes are not consumed by the reactions they catalyze, nor do they alter the equilibrium of these reactions. However, enzymes do differ from most other catalysts by being much more specific.

Enzymes being selective and specific in action catalyze desired reaction, excluding side reactions and thereby eliminating generation of undesirable by products. Thus using enzymes in industry, higher productivity is achieved, reducing material cost. Further purification and downstream processing is reduced as product is achieved in relatively pure from, free from contaminants. ${ }^{1}$

Enzymes offer substantial and increasingly important advantages over chemical catalysts; they are derived from renewable resources, are biodegradable, work under relatively mild conditions of temperature and $\mathrm{pH}$, and tend to offer exquisite selectivity in both reactant and product stereochemistry. As concerns about the environment mount with population pressures and the industrialization of the planet, the need to find more benign methods for the production of goods and provision of services leads to further interest in enzymes. ${ }^{2}$

Enzymes can be of Plant, animal and microbial origin. Microbial enzymes have several advantages over enzymes from plant and animal sources by virtue of their great variety of catalytic activities, cheaper in cost, regular abundant supplies at even quantity and relatively more stability. Major target of modern enzyme technology continues to be providing substitutes for chemical processing in several industries including textile, pharmaceutical, leather, wood pulp, production of speciality chemicals, industrial catalysis etc. Further enzymes have been used as research tool in biotechnology and molecular biology. The global industrial enzymes market is projected to reach USD 6.30 Billion by 2022 in terms of value, at a CAGR of $5.8 \%$ from $2017 .{ }^{3}$

Although the advantages of replacing chemical treatments with enzymes are often compelling from a societal and environmental viewpoint, enzymes must compete economically with often entrenched and extremely inexpensive traditional chemical processes. ${ }^{2}$

\section{Marine microbial enzymes}

Now-a-days microorganisms are being used due to their broad biochemical diversity, feasibility of mass culture, regular supply due to absence of seasonal variations, ease of genetic manipulation and high degree of stability than enzymes derived from plants and animals. ${ }^{4}$ Several industrial enzymes are derived from terrestrial sources. Whereas marine environment which encompasses about 71 $\%$ of the earth's surface and a vast resource of useful enzymes has remain unexplored. Marine ecosystem is a habitat with remarkably high and diverse microbial cell densities. Consequently, the microbial inhabitants of such environment must have adapted their cellular machinery to thrive in the extreme conditions of temperature, pressure, $\mathrm{pH}$, salinity, etc. Earlier reports suggest their salttolerating capacity of above $1.7 \mathrm{M}$, hyperthermostability $\left(80-108^{\circ} \mathrm{C}\right)$, barophilicity (60MPa), cold adaptivity, and alkali stability. ${ }^{4}$ Marine microorganisms take active part in the mineralization of complex organic matter through degradative pathways of their metabolism in the marine environments and contribute to the secondary production in sea. Microbial hydrolysis of organic matter plays an important role in substrate turnover in aquatic environments. ${ }^{5}$ Most of the organic compounds produced in natural waters have a polymeric structure. ${ }^{6}$ They cannot be directly taken by bacteria and they must be hydrolysed through the action of exo and endoenzymes and converted 
into monomeric low molecular weight substrates. These are rapidly assimilated by bacteria. ${ }^{7}$

Depending on habitat and ecological function, marine bacteria and fungi secrete variety of hydrolytic enzymes such as Pectinase, Amylase, Lipase, Protease etc. Marine microbial enzymes have now become focal point of interest and few enzymes have been isolated from sea water and sediment. With increase in demand of the industrially valuable enzymes, selection of their potent source has become need of hour. Valuable extremophilic marine microorganisms capable of producing various hydrolytic enzymes like proteases, lipases, pectinases, etc. are inhabiting the harsh marine environments such as deep ocean, sediments, hydrothermal vents, polar oceans and extremely saline bodies of water.

\section{Pectinase and its application}

Pectinases are a diverse group of enzymes that catalyze breakdown of pectic substances. Pectin is present as a cementing substance in plant cell wall and it maintains structural integrity and cohesion of plant tissue. ${ }^{8}$ Depending on mode of action, pectinases are classified as esterases, depolymerases (hydrolases and lyases), and protopectinases. ${ }^{9}$ Acidophilic pectinases have been used widely in extraction and clarification of fruit juices, ${ }^{10}$ maceration of plant tissues, liquefaction and saccharification of biomass and isolation of protoplast. Alkaline pectinases are mainly used in the degumming and retting of fiber crops ${ }^{11}$ and pretreatment of pectic wastewater from fruit juice industries. ${ }^{12}$ Alkaline pectinases are also being used in paper making, ${ }^{13}$ scouring of cotton, ${ }^{14}$ oil extraction, ${ }^{15}$ coffee ${ }^{16}$ and tea fermentation, ${ }^{17}$ production of oligosaccharides as functional food components ${ }^{18}$ and extraction of DNA from plants. ${ }^{19}$ Different enzymes such as amylase, lipase, pectinase, and cellulase have been studied in scouring of natural fabrics. Out of these enzymes, pectinases are most promising enzymes and different organisms producing pectinases are being researched.

\section{Enzymes in textile industry}

Textile wet processing involves series of operations ranging from desizing, scouring, bleaching followed by dyeing and finishing. These operations involve use of harsh chemicals such as caustic soda, concentrated acid and salt solutions which are finally discharged into effluents, causing pollution of soil and water, affecting aquatic life. However, enzymes bestow green key to minimize pollution resulting from textile processing operations. Amylase, lipase, protease, cellulase, pectinase etc. are some of the enzymes that can be used as substitute to different chemicals used in textile wet processing steps. Amylase find application in desizing of cotton fabric wherein amylase act on starch used as sizing agent to facilitate weaving (added impurity) from cotton fabric and aids in its removal. Cellulase has been studied for defibrillating cotton for surface smoothness and to obtain stone washing effects. Lipase has been used for wet reduction of polyester fabric and protease for degumming of silk and scouring of wool. Different enzymes such as amylase, lipase, pectinase, and cellulase have been studied in scouring of natural fabrics in combination. Out of these enzymes, pectinases are most promising enzymes and different organisms producing pectinases are being researched. Enzymes such as laccases and peroxidises have been used in effluent treatment. Different enzymes are being researched upon for their subsequent use in textile processing as till now only amylase and cellulase have achieved commercial success.

\section{Immobilization of marine pectinase}

The major demands of the world's biotechnological industries are enhancement in enzyme productivity and development of novel techniques for increasing their shelf life. These requirements are inevitable to facilitate large-scale and economically feasible formulation. Enzyme immobilization provides an excellent base for increasing availability of enzyme to the substrate with greater turnover over a considerable period of time. Biocatalysis i.e. catalysis using enzymes has been widely accepted in diverse sectors owing to their ease of production, substrate specificity and green chemistry.

Enzyme-based strategies are increasingly replacing conventional chemical methods in both laboratories and industries with attributes like efficiency, quicker performance and multifarious use. However, for commercialization of these biocatalysts, their reusability factor becomes mandatory, failing which they would no longer be economic. Maintenance of their structural stability during any biochemical reaction is highly challenging. Consequently, immobilized enzymes with functional efficiency and enhanced reproducibility are used as alternatives in spite of their expensiveness.

Immobilized biocatalysts can either be enzymes or whole cells. ${ }^{20}$ Whole cell immobilization consists of high density of cells physically confined on a solid phase or in pellets or clumps and in which cell movement is restricted. Cell immobilization has existed or been exploited long before it became recognized as potentially valuable in industry. Microorganisms in natural habitats such as soil, marine, alimentary canal, dental plaque or in the 'Orleans' process of vinegar production where cells are immobilized on wood shavings, the activated and trickling filter treatment of wastewater, may be seen as examples of immobilized cells. ${ }^{21}$

\section{Advantages of immobilized biocatalysts}

The advantages of immobilized enzymes beside reuse are as follows;

a. They can be easily separated from the reaction mixture containing any residual reactants and products and further can be reused in subsequent reaction.

b. Immobilized enzymes are more stable over broad range of $\mathrm{pH}$ and temperature.

c. Prolonged availability curtails redundant downstream and purification processes

d. Enzymes are not discharged in effluent.

e. Immobilized systems specially lend themselves to continuous processes.

f. Reduced costs in industrial production.

g. Greater control of the catalytic effect.

h. Superior ease of new applications for industrial and medical purposes.

\section{Enzyme immobilization}

It refers to artificial restriction of enzyme's mobility. Immobilization confines enzyme to a phase (matrix/support) different from the one for substrates and products. Inert polymers and inorganic materials are usually used as carrier matrices. Apart from 
being affordable, an ideal matrix must encompass characteristics like inertness, physical strength, stability, regenerability, ability to increase enzyme specificity/activity and reduce product inhibition, nonspecific adsorption and microbial contamination ${ }^{22}$ Immobilization is one of the most promising techniques for highly efficient and economically competent biotechnological processes in the field of environmental monitoring, biotransformation, diagnostics, pharmaceutical and food industries. There are four different methods of immobilizing enzymes viz. Adsorption, Covalent bonding, Entrapment and Affinity immobilization.

An attempt is made in this research to immobilize pectinase on knitted nylon 6,6 fabric by covalent attachment of enzyme molecules which will allow its reusability and in turn will make pectinase economical in use. The literature survey shows that knitted nylon fabric gives better yields as compared to nylon beads and hence, the substrate chosen was knitted nylon 6,6 fabric. ${ }^{23}$

\section{Experimentation}

\section{Immobilization of marine pectinase on nylon}

Acid hydrolysis of nylon 6, 6: The knitted nylon fabric $(3 \mathrm{~cm} \times 3 \mathrm{~cm})$ was used as substrate for immobilization of marine pectinase. In order to cleave amide bonds of the nylon polymer and create more $-\mathrm{COOH}$ and $-\mathrm{NH}_{2}$ groups on its surface, hydrolysis of nylon was carried out using $\mathrm{HCl}$ of varied molarity. The samples were placed in beaker and hydrolysis of nylon 6,6 was carried out at $30^{\circ} \mathrm{C}$ for 1 hour using $\mathrm{HCl}$ of different molarity. Hydrochloric acid concentration was varied from $1 \mathrm{M}, 2 \mathrm{M}, 3 \mathrm{M}, 4 \mathrm{M}$. After hydrolysis, the fabric pieces were rinsed with water and later with phosphate buffer, $\mathrm{pH}$ 7.0. After optimizing acid concentration, time required to achieve sufficient acid hydrolysis was optimized.

Knitted nylon fabric samples were treated with $1.25 \%$ and $2.5 \%$ gluteraldehyde solution $(\mathrm{v} / \mathrm{V})$ prepared in $0.2 \mathrm{M}$ Tris buffer $(\mathrm{pH} 9.0$ ) for $30 \mathrm{mins}$ at $250 \mathrm{rpm}$ and MLR 1:20. Glutaraldehyde was employed to act as cross linking agent between hydrolyzed nylon and pectinase enzyme. After treatment, the fabrics were washed thoroughly with Distilled water in order to remove unreacted glutaraldehyde and then rinsed with $0.2 \mathrm{M}$ Phosphate buffer ( $\mathrm{pH} 7.0)$.

Activated nylon samples were then immersed in $0.5 \mathrm{M} 1$, 6-hexanediamine solution keeping MLR as 1:20 and allowed to react for 120 mins. Samples were then washed thoroughly with $\mathrm{D} / \mathrm{W}$ and then rinsed with $0.2 \mathrm{M}$ Phosphate buffer ( $\mathrm{pH}$ 7.0). After introduction of spacer, all nylon samples were then reactivated with $2.5 \%$ and $1.25 \%$ gluteraldehyde solution $(\mathrm{v} / \mathrm{V})$ prepared in $0.2 \mathrm{M}$ Tris buffer (pH 9.0). Treatment is given for 30 mins at $250 \mathrm{rpm}$, keeping MLR at 1:20. Fabrics were washed thoroughly with $\mathrm{D} / \mathrm{W}$ in order to remove unreacted glutaraldehyde and then rinsed with $0.2 \mathrm{M}$ Phosphate buffer ( $\mathrm{pH} 7.0)$.

\section{Immobilization of marine pectinase on functionalized nylon}

Functionalized nylon fabrics were then incubated overnight with marine pectinase at $\mathrm{pH} 9.0$ and at $4^{\circ} \mathrm{C}$. Supernatant was then analysed for pectinase activity (by DNSA method) and protein content by Folin- Lowry method. Two schemes were followed for studying immobilization of marine pectinase on functionalized nylon fabric. In first scheme, marine pectinase was allowed to react with hydrolyzed nylon fabric activated by glutaraldehyde, whereas in second scheme, spacer molecule was introduced and nylon fabric was reactivated with glutaraldehyde which was later treated with marine pectinase.

\section{Determination of activity of immobilized pectinase}

Activity was determined by DNSA method and absorbance was recorded at $540 \mathrm{~nm}$. To perform an assay, $0.07 \mathrm{gm}$ of immobilized nylon sample was soaked in tris buffer and $0.5 \%$ Polygalacturonic acid (substrate) and incubated for 30 mins at $40^{\circ} \mathrm{C}$ to carry out pectinase assay. After incubation, the nylon fabric was removed with forcep, rinsed with $\mathrm{D} / \mathrm{W}$ and stored for reuse. $1.0 \mathrm{ml} \mathrm{DNSA}$ reagent was then added to assay test tubes and kept in boiling water bath for 5 minutes; test tubes were cooled and absorbance was recorded at 540 $\mathrm{nm}$. Activity of marine pectinase was determined in $\mathrm{U} / \mathrm{mg}$ of substrate used. To compare activity of immobilized pectinase with that of free pectinase, Conversion factor of 0.0043 was used to convert activity of immobilized pectinase from $\mathrm{U} / \mathrm{mg}$ to $\mathrm{U} / \mathrm{ml}$. Conversion factor was derived from ratio of volume of marine pectinase used for immobilization ( $1 \mathrm{ml})$ to Weight of nylon fabric taken $(230 \mathrm{mg})$.

\section{Definition of yield}

Immobilization yield (IY\%) is defined as follows: IY\% $=\left(\mathrm{U}_{\mathrm{imb}} /\right.$ $\left.U_{0}\right) \times 100$. Where $U_{0}$ is the number of enzymatic units present in the solution used for immobilization, $U_{\text {imb }}$ are the immobilized units evaluated as the difference between $\mathrm{U}_{0}$ and those remaining in the supernatant at the end of the adsorption.

\section{Effect of $\mathrm{pH}$ on immobilized pectinase activity}

To asses effect of $\mathrm{pH}$ on immobilized pectinase, different buffers $(20 \mathrm{mM})$ namely, Phthalate- $\mathrm{HCl}$ buffer $(\mathrm{pH} 3.0)$, Acetate buffer $(\mathrm{pH}$ 5.0), Phosphate buffer ( $\mathrm{pH} 7.0$ ), Tris buffer ( $\mathrm{pH} 9.0$ ) and Carbonate bicarbonate buffer ( $\mathrm{pH} 11.0$ ) were employed. The pectinase assay was carried out at mentioned $\mathrm{pH}$ values at $40^{\circ} \mathrm{C}$ for $30 \mathrm{~min}$.

\section{Effect of temperature on immobilized pectinase activity}

Optimum temperature for immobilized pectinase activity was determined by incubating immobilized pectinase enzyme, with $0.5 \%$ PGA at various temperatures ranging from $0^{\circ} \mathrm{C}$ to $80^{\circ} \mathrm{C}$ in Tris buffer (pH 9.0) for 30 mins. Further DNSA method was followed as mentioned above to determine activity of immobilized pectinase.

\section{Reusability of Immobilized marine pectinase}

To check reusability of Immobilized marine pectinase, $0.07 \mathrm{gm}$ of immobilized nylon sample was soaked in tris buffer and Polygalacturonic acid (substrate); and incubated for $30 \mathrm{mins}$ at $40^{\circ} \mathrm{C}$ to carry out pectinase assay. After incubation and before adding DNSA reagent, the nylon fabric sample was removed using forceps from test tube and washed with $\mathrm{D} / \mathrm{W}$ to evaluate further residual pectinase activity. This procedure was repeated until pectinase activity was decreased upto $25 \%$ of initial immobilized pectinase activity.

\section{Statistical analysis}

It is to be noted that all the experiments were conducted in triplicate and results were expressed as mean \pm standard deviation. Student's T test was used to analyse data and statistical significance was declared at $\mathrm{p}<0.05$. 


\section{Results and discussion}

\section{Effect of $\mathrm{HCl}$ concentration on hydrolysis of nylon}

Nylon-6,6 has only few free end groups which could be used for covalent attachment of enzyme molecules. In order to increase the amount of potentially reactive groups on nylon 6,6 surface; it was subjected to partial acid hydrolysis. Acid hydrolyzes amide (-CO$\mathrm{NH}-$ ) groups that lead to the increase in the yield of free amino and carboxyl groups on the polymer surface. Both the carboxyl and amino groups of the partially hydrolyzed nylon can be used for the direct attachment of the enzyme molecules. Various chemical reactions have been utilized in enzyme immobilization. ${ }^{24}$ Although the reaction mechanisms are varied, most of them select amine groups in enzymes, including $-\mathrm{NH}_{2}$ of lysine residue and the $-\mathrm{NH}_{2}$ terminal, as the reaction target. The reason is, first most of the proteins show many lysine residues that are usually not involved in catalytic site. Secondly amine groups are polar and they are usually exposed to the medium on the protein surface. Finally, amino groups, when they are unprotonated, are very reactive, without previous activation..$^{25}$

To determine optimum $\mathrm{HCl}$ concentration, activity of immobilized

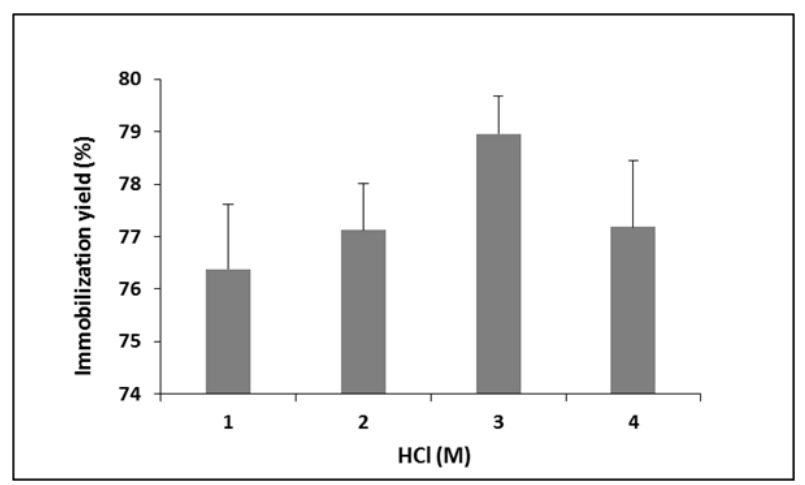

Figure I Effect of acid hydrolysis on immobilization of marine pectinase in presence of spacer.

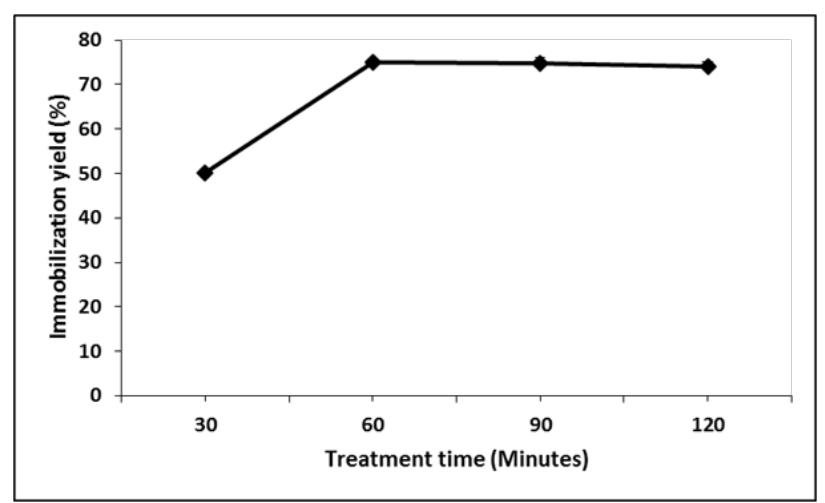

Figure 3 Effect of treatment time on hydrolysis of $\mathrm{Nylon}$ by $\mathrm{HCl}$ in presence of spacer.

Effect of glutaraldehyde concentration on pectinase immobilization

$1.25 \%$ and $2.5 \%$ glutaraldehyde solution prepared in Tris buffer were used as cross linking agent for immobilization of pectinase enzyme. The role of glutaraldehyde is considered to be a cross linking pectinase was determined, using each concentration of $\mathrm{HCl}$. As can be seen from (Figure 1) (Figure 2), $3 \mathrm{M} \mathrm{HCl}$ was found to be optimum to achieve hydrolysis of nylon. Increasing concentration of $\mathrm{HCl}$ to $4 \mathrm{M}$ lead to no appreciable increase in immobilized enzyme activity. Using both scheme I and scheme II, $3 \mathrm{M} \mathrm{HCl}$ concentration was taken as optimum concentration to achieve maximum immobilized pectinase activity. It is also reported $2.9 \mathrm{M} \mathrm{HCl}$ to be optimum to achieve hydrolysis of nylon $6,6 .{ }^{26}$

\section{Effect of treatment time on hydrolysis of nylon by $\mathrm{HCl}$}

Treatment time of 60 minutes was found to be optimum to achieve maximum immobilization yield of marine pectinase both in presence and absence of spacer (Figure 3)(Figure 4). Prolonged hydrolysis of nylon using $3 \mathrm{M} \mathrm{HCl}$, lead to no appreciable increase in immobilized pectinase activity. Prolonged hydrolysis must have generated more$\mathrm{NH}_{2}$ groups leading to multiple binding sites linked to individual pectinase molecules. This in turn might lead to some inactivation of the marine pectinase or modification or masking of catalytic sites which would be consistent with the fall in apparent activity at longer hydrolysis times

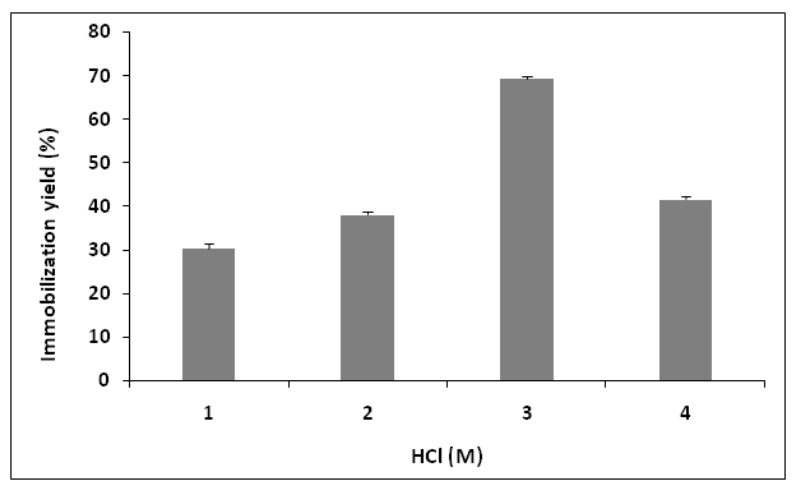

Figure 2 Effect of acid hydrolysis on immobilization of marine pectinase in absence of spacer.

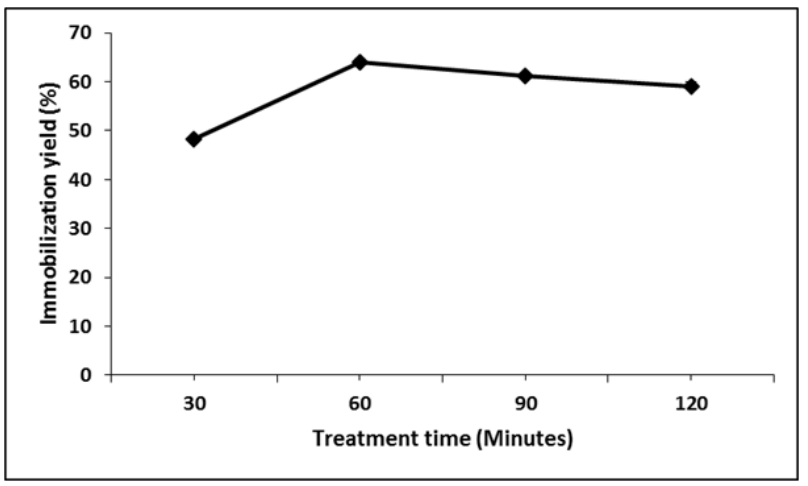

Figure 4 Effect of time on hydrolysis of $\mathrm{Nylon}$ by $\mathrm{HCl}$ in absence of spacer

agent wherein, the proximal aldehyde group in each glutaraldehyde molecule would link in the classical Schiff's base fashion with the amine groups of the spacer molecules, leaving the distal aldehyde group available for covalent enzyme coupling. Different scientists have reported different concentrations of glutaraldehyde for immobilizing different enzymes on various supports. 
As can be observed from Figure 5 and Figure 6, 2.5\% glutaraldehyde is optimum to achieve maximum immobilization yield both in presence and absence of spacer than $1.25 \%$ glutaraldehyde. It is indicated that low concentrations of glutaraldehyde were not able to form sufficient crosslinkages to effect precipitation of the enzyme. ${ }^{27}$ At higher concentrations; the extent of crosslinking was high enough to form a tight structure by excluding water molecules

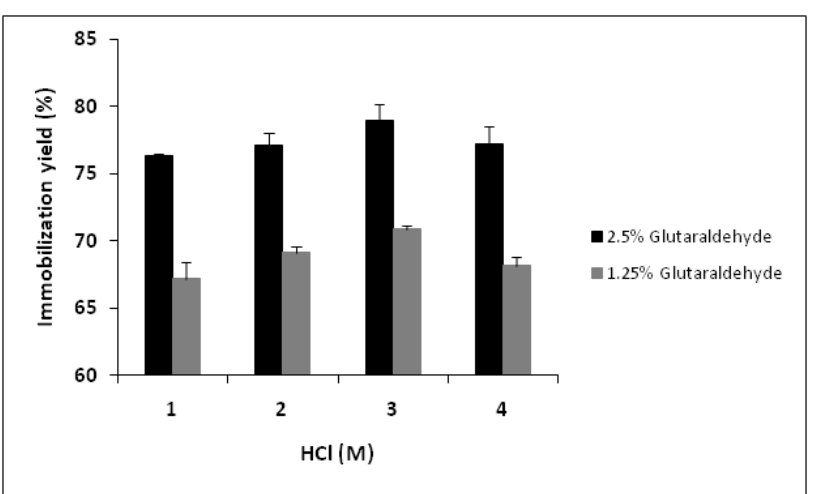

Figure 5 Effect of glutaraldehyde concentration on pectinase immobilization in presence of spacer.

Thus it was observed that immobilization yield of marine pectinase on nylon is higher in presence of spacer, 1,6 hexanediamine. The introduction of a hydrophilic spacer could increase the immobilized enzyme's stability.

The other purpose of using a spacer is to enable the immobilized enzyme to be in a less tight spatial confirmation, i.e. providing more space between the cross-linked enzyme molecules and the surface of the support matrix to facilitate the said molecules maintain their predetermined spatial arrangement for proper enzyme function. Moreover, the presence of an amino containing spacer, such as 1,6 hexanediamine, will increase the binding points on the carrier resulting in enhancement in immobilized activity. ${ }^{26}$

\section{Effect of $\mathrm{pH}$ on activity of immobilized pectinase}

As can be observed from Figure 7, $\mathrm{pH} 9$ is found to be optimum for maximum immobilized pectinase activity. Free pectinase also showed maximum activity at alkaline $\mathrm{pH}$ 9.0. Further line graph for effect of

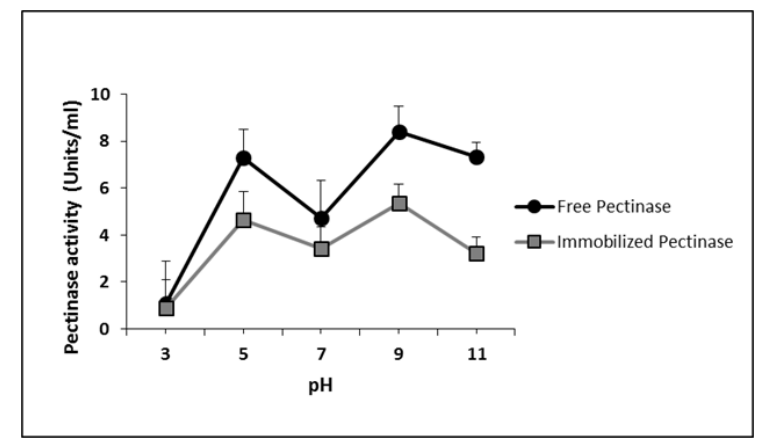

Figure 7 Effect of $\mathrm{pH}$ on immobilized pectinase.

\section{Reusability of enzyme}

Pectinase enzyme immobilized on nylon could be used successfully up to 3 wash cycles. To determine reusability of pectinase, residual activity of immobilized pectinase was determined after each wash to insolubilize the enzyme derivative. However, higher concentration of glutaraldehyde leads to negligible immobilization yield of marine pectinase. This may be because of extensive cross linking those results in distortion of enzyme structure. With this distortion, the accessibility and accommodation of the substrate may be reduced, thus affecting the retention of biological activity. ${ }^{28}$

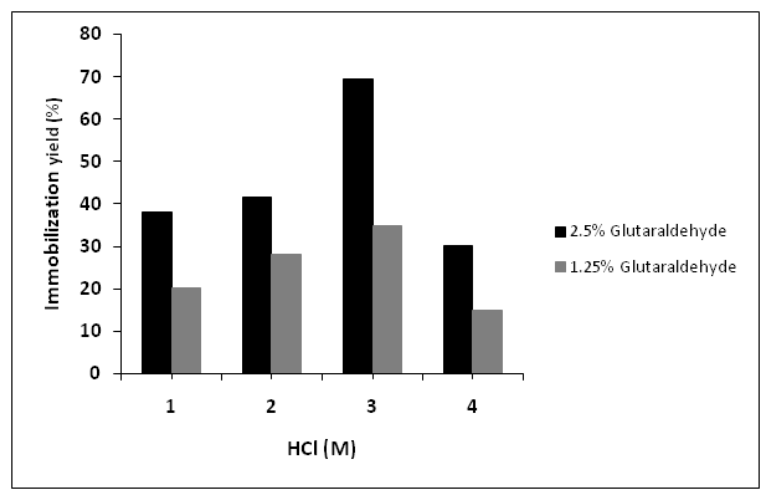

Figure 6 Effect of glutaraldehyde concentration on pectinase immobilization in absence of spacer.

$\mathrm{pH}$ on free and immobilized pectinase follows similar pattern.

\section{Effect of temperature on immobilized pectinase}

The optimum temperature of the free pectinase was $60^{\circ} \mathrm{C}$ but after the immobilization via crosslinking on nylon, a shift in such temperature was observed and the immobilized pectinase exhibited the highest activity at $80^{\circ} \mathrm{C}$ (Figure 8), since hydrophobic and other secondary interactions of the immobilized enzyme might impair conformational flexibility needing higher temperatures for the enzyme molecule to recognize and attain a proper conformation in order to retain its reactivity. ${ }^{29}$ Thereafter, a loss in activity above $80^{\circ} \mathrm{C}$ might be due to the denaturation of some enzyme molecules.

Lower activity of the immobilized pectinase has been observed during these assays as compared to the free enzyme. It might be due to decreased affinity of pectinase for the substrate caused by internal diffusion of the immobilized enzyme. ${ }^{30}$

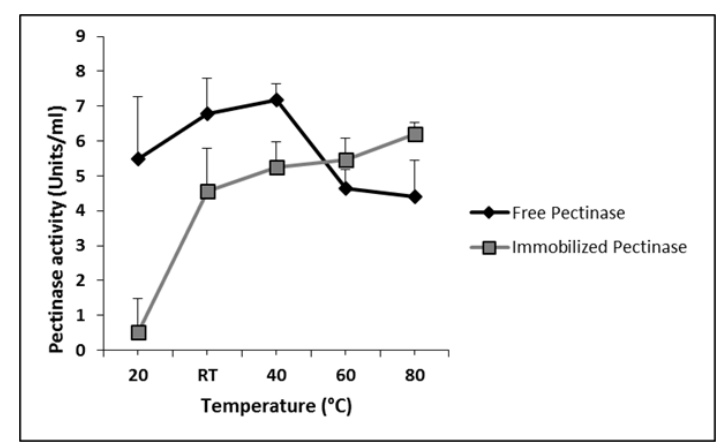

Figure 8 Effect of temperature on immobilized pectinase.

cycle. After 3 wash cycles immobilized pectinase showed $25 \%$ of its initial activity. Thus the immobilized enzyme activity decreased with increasing number of uses. These results could be explained by the inactivation of enzyme caused by the denaturation and the leakage 
of enzyme from support upon use and diffusion inside the matrix limiting accessibility of enzyme. ${ }^{31}$ As an outcome, the immobilized enzyme offers repeated uses whereas the free enzyme can only be used one time except when recovered from the reaction mixture without any denaturation. ${ }^{32}$ The immobilized pectinase retained more than $75 \%$ residual activity after first cycle; $39 \%$ on its second cycle and $21 \%$ after third cycle.

\section{Conclusion}

Marine environment represents untapped and rich source of both chemical and biological diversity. Marine microorganisms have evolved greatest metabolic and genetic diversity in order to adapt to extreme conditions. In order to increase reusability of marine pectinase, it was immobilized on knitted nylon 6,6, fabric using glutaraldehyde as cross linking agent. Under optimized conditions immobilization yield was found to be $78 \%$ and $69 \%$ in presence and in absence of spacer respectively. Immobilized pectinase showed higher optimum temperature as compared to free pectinase while optimum $\mathrm{pH}$ remained same. Immobilized pectinase biocatalyst could be used repetitively up to 3 cycles.

Thus, it can be stated extracellular pectinase produced by marine B. subtilis was successfully immobilized on nylon 6,6 .

\section{Acknowledgements}

I would like to acknowledge UGC for fellowship and contingency.

\section{Conflict of interest}

There is no conflict of interest

\section{References}

1. Sanchez S, Demain AL. Enzymes and bioconversions of industrial, pharmaceutical and biotechnological significance. Organic Process Research \& Development. 2011;15(1):224-230.

2. Cherry JR, Fidantsef AL. Directed evolution of industrial enzymes: an update. Current Opinion in Biotechnology. 2003;14(4):438-443.

3. Rohan. Industrial Enzymes Market by Type (Amylases, Cellulases, Proteases, Lipases, and Phytases), Application (Food \& Beverages, Cleaning Agents, and Animal Feed), Source (Microorganism, Plant, and Animal), and Region - Global Forecast to 2022. Markets and Markets. 2016.

4. Singh K, Richa K, Bose H, et al. Statistical media optimization and cellulase production from marine Bacillus VITRKHB. 3 Biotech. 2010;4(6):591-598.

5. Kim SJ, Hoppe HG. Microbial extracellular enzyme detection on agar by means of fluorogenic methylumbelliferyl substrates. Deuxième Colloque International de Bactériologie marine. 1984;3:175-183.

6. Somville M. Measurement and study of substrate specificity of exoglucosidase activity in eutrophic water. Appl Environ Microbiol. 1984;48:1181-1185.

7. Billen G, Fontigny A. Dynamics of Phaeocystis-dominant spring bloom in Belgian coastal waters. Il. Bacterioplankton dynamics. Marine Ecology Progress Series. 1987; 37(2/3):249-257.

8. Chrost RJ. Environmental control of the synthesis and activity of aquatic microbial ectoenzymes. Microbial Enzymes in Aquatic Environments. 1991:29-59.
9. Jayani RS, Saxena S, Gupta R. Microbial pectinolytic enzymes: A review. Process biochemistry. 2005;40(9):2913-2944.

10. Joshi VK, Parmar M, Rana N. Purification and characterization of pectinase produced from apple pomace and evaluation of its efficacy in fruit juice extraction and clarification. Indian $J$ natural products \& resources. 2011;(2):189-197.

11. Saleem Z, Rennebaum H, Pudel F, et al. Treating bast fibres with pectinase improves mechanical characteristics of reinforced thermoplastic composites. Composites Science and Technology. Composites Science \& Technology. 2008;68(2):471-476.

12. Tanabe H, Yoshihara K, Tamura K, et al. Pretreatment of pectic waste water from orange canning process by an alkaophilic Bacillus species. J Fermentation Technology. 1987; 65(2):243-246.

13. Reid I, Ricard M. Pectinase in paper making: Solving retention problems in mechanical pulp, bleached with hydrogen peroxide. Enzyme Microb Technol. 2000;26(2-4):115-123.

14. Kalantzi S, Diomi M, Emmanuel K, et al. Improved Properties of Cotton Fabrics Treated with Lipase and Its Combination with Pectinase. Fibres \& Textiles of Eastern Europe. 2010;18(5):86-92.

15. Najafian L, Ghodsvali A, Khodaparast MHH, et al. Aqueous extraction of virgin olive oil using industrial enzymes. Food Research Internatioanl. 2009;42(1):171-175.

16. Murthy SP, Naidu MM. Improvement robusta coffee fermentation with microbial enzymes. European J Applied Sciences. 2011;3(4):130-139.

17. Thakur J, Gupta R. Improvement of tea leaves fermentation through pectinases. Acta Microbiologica etImmunologica Hungarica. 2012;59(3):321-334.

18. Combo AMM, Aguedo M, Goffin D, et al. Enzymatic production of pectic oligosachharides from polygalacturonic acid with commercial pectinase preparations. Food \& Bioproducts Processing. 2012;90(3):588-596.

19. Rogstad SH, Keane B, Keiffer CH, et al. DNA extraction from plants: The use of Pectinase. Plant molecular biology reporter. 2001;19(4):353-359.

20. Datta S, Christena LR, Rajaram YR. Enzyme immobilization: an overview on techniques and support materials. 3 Biotech. 2013;3(1):1-9.

21. Chibata I, Tosa T, Sato T. Biocatalysis: immobilized cells and enzymes. $J$ Molecular Catalysis. 1986;37(1):1-24.

22. Singh BD. Biotechnology expanding horizons. India: Kalyani; 2010. 925 p.

23. Shukla SR, Jajpura Lalit. Immobilisation of amylase by various techniques. Indian J Fibre \& Textile Research. 2005;29:75-81.

24. Huang LK, Mahoney RR. Purification and characterization of an endopolygalacturonase from Verticillium alboatrum. $J$ Applied Microbiology. 1999:86(1):145-156.

25. Guisan J. Aldehyde-agarose gels as activated supports for immobilizationstabilization of Enzymes. Enzyme \& Microbial Technology. 1988;10(6):375-382.

26. Isgrovea FH, Williams RJ, Niven GW, et al. Enzyme immobilization on nylon- optimization and the steps used to prevent enzyme leakage from the support. Enzyme Microb Technol. 2001;28(2-3):225-232.

27. Broun GB. Chemically aggregated enzymes. Methods in Enzymol. $1976 ; 44: 263-280$.

28. Chui WK, Wan LS. Prolonged retention of cross-linked trypsin in calcium alginate microspheres. J Microencapsulation. 1997;14(1):51-61. 
29. Munjal N, Sawhney SK. Stability and properties of mushroom tyrosinase entrapped in alginate, polyacrylamide and gelatin gels. Enzyme \& Microbial Technology. 2002;30(5):613-619.

30. Nunes MAP, Vila-Real H, Fernandes PC, et al. Immobilization of naringinase in PVA-alginate matrix using an innovative technique. Applied Biochemistry \& Biotechnology. 2010;160(7):2129-2147.

31. Ye $\mathrm{P}, \mathrm{Xu} \mathrm{JK}, \mathrm{Wu} \mathrm{J}$, et al. Nanofibrous poly (acrylonitrile-co-maleic acid) membranes functionalized with gelatin and chitosan for lipase immobilization. Biomaterials. 2006;27(22):4169-4176.

32. Rehman H, Aman A, Silipo A, et al. Degradation of complex carbohydrate: Immobilization of pectinase from Bacillus licheniformis KIBGE-IB21 using calcium alginate as a support. Food Chemistry. 2013;139(1-4):1081-1086 